\title{
Chemical and biological control of Sclerotinia stem rot in the soybean crop
}

\author{
Controle químico e biológico da podridão branca da haste na cultura da soja
}

\author{
Ciro Hideki Sumida ${ }^{\mathrm{I}^{*}}$ Marcelo Giovanetti Canteri ${ }^{\mathrm{I}}$ Douglas Casaroto Peitl ${ }^{\mathrm{I}}$ \\ Fabiana Tibolla ${ }^{\mathrm{I}}$ Idenize Pedrina Orsini ${ }^{\mathrm{I}}$ Felipe André Araújo ${ }^{\mathrm{I}}$ \\ Débora Fonseca Chagas ${ }^{I}$ Natália Sanches Calvos ${ }^{I}$
}

\begin{abstract}
It was evaluated the effect of fungicides and the microbial control agent Trichoderma harzianum on the inhibition of the carpogenic and ascospore germination of Sclerotinia sclerotiorum. This study also evaluated the chemical, fungicidal and microbial control of white mold or Sclerotinia stem rot of soybean in the field. Three experiments were conducted, as follows: 1) inhibition of carpogenic germination of sclerotia, 2) inhibition of ascospore germination, and 3) control of Sclerotinia stem rot in a soybean crop under field conditions. The treatments evaluated were fluazinam, procymidone, iprodione, thiophanatemethyl, carbendazim, benzalkonium chloride + fluazinam, and $\boldsymbol{T}$. harzianum. Procymidone resulted in an inhibition of $13.5 \%$ and benzalkonium chloride in an inhibition of $13.9 \%$ in an ascospore germination test. Fluazinam and procymidone were the most effective in reducing the production of ascospores/apothecium, representing $65.6 \%$ and $82.4 \%$ of inhibition. Procymidone and fluazinam if combined or not with benzalkonium chloride were the most effective in controlling sclerotinia stem rot under field conditions when applied at the onset of flowering and 15 days later. In the 2009-10 harvest, these two fungicides reduced the incidence of Sclerotinia stem rot by 73.1 and $71.6 \%$ and in the 2010-11 harvest by 75.7 and $77.6 \%$, respectively.
\end{abstract}

Key words: Glycine max, Trichoderma harzianum, apothecium, ascospore, sclerotium, soybean.

\section{RESUMO}

Avaliaram-se o efeito de fungicidas e agente de controle biológico Trichoderma harzianum na inibição da germinação carpogênica e de ascósporos de Sclerotinia sclerotiorum. Também foram avaliados os controles químico e biológico do mofo branco ou podridão branca da haste na cultura da soja em condições de campo. Foram desenvolvidos três ensaios, sendo: 1) inibição da germinação carpogênica; 2) inibição da germinação de ascósporos; e 3) controle da podridão branca da haste na cultura da soja em condições de campo. Os tratamentos avaliados foram fluazinam, procimidona, iprodione, tiofanato metílico, carbendazim, cloreto de benzalcônio + fluazinam e $\boldsymbol{T}$. harzianum. O procimidona resultou em inibição de 13,5\% e o cloreto de benzalcônio + fluazinam em 13,9\% de inibição no teste de inibição da germinação dos ascósporos. Fluazinam e procimidona foram os mais eficientes na redução da produção de ascósporos/ apotécio representando $65,6 \%$ e $82,4 \%$ de inibição. O procimidona efluazinam se combinados com cloreto de benzalcônio ou não foram os mais eficientes no controle da podridão branca da haste em condições de campo, quando aplicados no início do florescimento e 15 dias após. Na safra 2009-10, esses dois fungicidas reduziram a incidencia da podridão branca da haste, em 73,1 e 71,6\% e, na safra 2010-11, reduziram em 75,7 e 77,6\%, respectivamente.

Palavras-chave: Glycine max, Trichoderma harzianum, apotécio, ascósporos, escleródio, soja.

\section{INTRODUCTION}

White mold or Sclerotinia stem rot caused by Sclerotinia sclerotiorum (Lib.) de Bary is a growing threat to the soybean crop (DHINGRA et al., 2009) and is of great concern to producers and researchers in countries such as Brazil (LOBO JUNIOR \& ABREU, 2000) and the United States, causing losses of some 1.6 million tons in 2004 alone (WRATHER \& KOENNING, 2011).

Conventional methods to control the disease include crop management (FERRAZ et al., 2003), use of resistant cultivars, and chemical control (BARDIN \& HUANG, 2001). With regard to chemical control, there are reports of inconsistent and ineffective results owing to application problems

IDepartamento de Agronomia, Universidade Estadual de Londrina (UEL), Rodovia Celso Garcia Cid, PR 445, Km 380, CP 6001, 86051-990, Londrina, PR, Brasil. E-mail: cirosumida@hotmail.com. *Corresponding author. Received 02.10.14 Approved 07.07.14 Returned by the author 11.29.14 CR-2014-0198.R3 
(COSTA \& COSTA, 2004); however, according to TU (1989), several fungicides are considered effective in controlling Sclerotinia stem rot and are recommended for application during flowering. MUELLER et al. (2004) have also reported the use of fungicides for controlling the disease as an effective control strategy because of the flexibility of application timing in comparison with other crop control methods. Alternative methods such as biological control have also been attempted (HJELJORD \& TROSMO, 2005) using fungi such as Trichoderma sp., which is characterized as a mycoparasite of $\boldsymbol{S}$. sclerotiorum, capable of colonizing mycelia (ABDULLAH et al., 2008) and sclerotia (HUANG \& ERICKSON, 2008).

Therefore, the aim of this study was to evaluate the effects of fungicides and a biological product based on Trichoderma harzianum on the inhibition of the carpogenic and ascospore germination of $\boldsymbol{S}$. sclerotiorum and the control of Sclerotinia stem rot in the soybean crop under field conditions.

\section{MATERIAL AND METHODS}

\section{Isolation of S. Sclerotiorum}

An isolate of $\boldsymbol{S}$. sclerotiorum was obtained by collecting diseased plants from commercial soybean crops in the municipality of Mauá da Serra, Paraná, Brazil. Sclerotia were produced, separated, and conditioned at $7.0 \pm 3^{\circ} \mathrm{C}$ for 8 months before use in the experiments.

Fungicide inhibition of carpogenic germination of $\boldsymbol{S}$. Sclerotiorum

The experiment was performed in plastic germination boxes ("gerboxes" of $0.11 \times 0.11 \times 0.35 \mathrm{~m}$ ) containing $0.24 \mathrm{~L}$ of soil [dark red latosol (Oxisol)] according to the method described by COSTA \& COSTA (2004) but with different numbers of sclerotia/ box. The experimental design was fully randomized with eight treatments and four replications. The soil was prepared by sieving, moistening and autoclaving for $2 \mathrm{~h}$ at $120^{\circ} \mathrm{C}$ and $1 \mathrm{~atm}$ pressure. After the soil was dried in an oven at $56^{\circ} \mathrm{C}$ for $24 \mathrm{~h}, 0.2 \mathrm{~L}$ of the soil and $0.06 \mathrm{~L}$ of sterilized distilled water were placed in each box. Then, 100 sclerotia/gerbox were placed in the soil and covered with $40 \mathrm{~mL}$ of the soil, forming a layer of approximately $2.0 \mathrm{~mm}$ thickness over sclerotia.

Treatments were prepared at the recommended doses in $0.06 \mathrm{~L}$ spray containers as follows: T1 (control), T2 (fluazinam $0.5 \mathrm{~L}$ of the active ingredient.ha ${ }^{-1}$ or $0.06 \mathrm{~g}$ a.i.gerbox ${ }^{-1}$ ), T3 (procymidone $0.5 \mathrm{~kg}$ a.i.ha ${ }^{-1}$ or $0.06 \mathrm{~g}$ a.i.gerbox ${ }^{-1}$ ), T4 (iprodione $0.5 \mathrm{~kg}$ a.i.ha ${ }^{-1}$ or $0.06 \mathrm{~g}$ a.i.gerbox ${ }^{-1}$ ),
T5 (thiophanate-methyl $0.5 \mathrm{~kg}$ a.i.ha ${ }^{-1}$ or $0.06 \mathrm{~g}$ a.i.gerbox $\left.{ }^{-1}\right), \mathrm{T} 6$ (carbendazim $0.5 \mathrm{~kg}$ a.i.ha ${ }^{-1}$ or $0.06 \mathrm{~g}$ a.i.gerbox ${ }^{-1}$ ), T7 (benzalkonium chloride $0.1 \mathrm{~kg}$ a.i.ha ${ }^{-1}$ or $0.012 \mathrm{~g}$ a.i.gerbox ${ }^{-1}+$ fluazinam $0.5 \mathrm{~kg}$ a.i.ha ${ }^{-1}$ or $0.06 \mathrm{~g}$ a.i.gerbox ${ }^{-1}$ ), and $\mathrm{T} 8$ (commercial product based on T. harzianum $5 \times 10^{10}$ conidia.ha $^{-1}$ or $6 \times 10^{6}$ conidia.gerbox $^{-1}$ ). Approximately $240 \mu \mathrm{L}$ $\left(200 \mathrm{Lha}^{-1}\right)$ of solution of fungicide and suspension of Trichoderma were sprayed into each gerbox, followed by incubation at $20 \pm 2^{\circ} \mathrm{C}$ for 45 days with a photoperiod of $12 \mathrm{~h}$. First, it was evaluated the number of germinated sclerotia, stipes, and apothecia, and then, it was calculated inhibition by comparing treatments with the control. The variables evaluated were the inhibition of sclerotia germination (ISG), inhibition of carpogenic germination (ICG), number of apothecia (NA), and number of stipes (NS). For the evaluation of ISG, a sclerotium was considered to be germinated if stipes were present, and/or apothecia had germinated, regardless of whether one or more stipes or one or more apothecia were present.

In this same experiment, it was also evaluated the ascospores germination. Five apothecia were removed from each replication and placed in microtubes containing $1.0 \mathrm{~mL}$ of sterilized distilled water. These apothecia were then crushed with tweezers to obtain a suspension of ascospores to determine the number of ascospores/apothecium using a hemacytometer. It was also placed $0.1 \mathrm{~mL}$ of the suspension in Petri dishes containing water - agar $(1 \mathrm{~L}-0.02 \mathrm{~kg})$ and incubated them in a BOD chamber at $20 \pm 2^{\circ} \mathrm{C}$ in darkness for $6 \mathrm{~h}$. After incubation, it was evaluated the number of germinated ascospores under a stereoscopic microscope and calculated the inhibition percentage in comparison with the control.

Fungicide inhibition of ascospore germination of $\boldsymbol{S}$. Sclerotiorum

It was evaluated the efficacy of the fungicides in direct contact with ascospores in Petri dishes containing water agar. The experimental design was fully randomized with eight treatments (see previous test) and five replications. Apothecia were obtained using the method described for the previous test, with the modification of using only five gerboxes. After day 45, the boxes were opened to identify mature apothecia based on the fact that ascospores were released from these apothecia. It was selected 10 mature apothecia from the five boxes and the stipes were sliced and crushed and, placed in $10-\mathrm{mL}$ crucibles with sterilized distilled water. Next, $0.1 \mathrm{~mL}$ of the ascospore suspension were placed in Petri dishes containing a water-agar culture medium 
and sprayed with approximately $160 \mu \mathrm{L}\left(200 \mathrm{Lha}^{-1}\right)$ of fungicide solutions obtained as described for the previous test. These Petri dishes were incubated in a BOD chamber at $20 \pm 2{ }^{\circ} \mathrm{C}$ in darkness for $6 \mathrm{~h}$ to determine ascospore germination using a stereoscopic microscope, and the inhibition percentage inhibition was calculated in comparison with the control.

Chemical control of Sclerotinia stem rot in a soybean crop Trials were conducted under field conditions in the municipality of Mauá da Serra, Paraná, Brazil, latitude 2351'06", longitude $51^{\circ} 10^{\prime} 40^{\prime \prime}$, elevation $970 \mathrm{~m}$. BRS283 soybean was sown under no tillage following oats in the 2009-10 harvest and wheat in 2010-11. The experimental area was subdivided into 32 plots of $4.0 \times 6.0 \mathrm{~m}\left(24 \mathrm{~m}^{2}\right)$; thus, the total area was of $768 \mathrm{~m}^{2}$. The experimental design was of randomized blocks with eight treatments (see previous test) and four replications.

Treatments were applied with a backpack sprayer pressurized with $\mathrm{CO}_{2}$ with four flat-fan nozzles of type AXI 110-02. Spray pressure was $206.8 \mathrm{kPa}$, and spray volume $200 \mathrm{~L}$ of water/ha. Trichoderma treatment was applied at stages V3 and $\mathrm{R} 1$ and the fungicides at stage R1 and 15 days later (R3). Temperature during these treatments was approximately $20-25^{\circ} \mathrm{C}$ and relative humidity $90-99 \%$.

At 95 DAS (days after sowing), it was evaluated the incidence (percentage of plants with symptoms) and severity of Sclerotinia stem rot using the scale of GRAU et al. (1982): 0, no symptoms; 1, lesion on lateral branches; 2 , lesion on the main stem; 3 , lesions on the main stem resulting in plant death. Scores were converted into angular values $\omega$ and then into infection intensity indices $I^{\prime}=\sin ^{2} \omega$ as proposed by AMARAL (1969). Four points/plot and 40 plants/point were evaluated. At approximately 120 DAS, were harvested by hand $4.0 \mathrm{~m}$ of the two central rows, totaling 8.0 linear meters of each plot. Then, it was evaluated the weight of grain/plot and moisture content. The weight of grain/ plot was transformed to kilograms/hectare $\left(\mathrm{kgha}^{-1}\right)$.

\section{Statistical analysis}

Data obtainedwere subjected to the ShapiroWilk normality test. Homogeneity of variances was tested using Hartley's Fmax test. Analysis of variance was performed using the Scott-Knott test at 5\% error probability. The Pearson correlation coefficient (r) was calculated to verify data correlation.

\section{RESULTS}

Fungicide inhibition of carpogenic germination of $\boldsymbol{S}$. Sclerotiorum

ISG was evaluated in terms of the percentage of sclerotia that produced apothecia or stipes, irrespective of the numbers of apothecia or stipes. Fluazinam, benzalkonium chloride + fluazinam, iprodione, and carbendazim exhibited the highest percentages of sclerotia inhibition at 63.9, $61.8,46.5$, and $44.4 \%$, respectively (Table 1 ).

ICG was evaluated by counting the total number of apothecia. The best results were obtained for fluazinam (100\% inhibition), benzalkonium chloride + fluazinam (82.8\%), and iprodione (63.1\%). These results differed statistically $(\mathrm{P}<0.05)$ from the

Table 1 - Percentage inhibition of sclerotia germination (ISG), inhibition of carpogenic germination (ICG), inhibition of ascospore germination (IAG), and number of ascospores produced/apothecium $(\mathrm{ASC} / \mathrm{APO} \times 1000)$ after fungicide application to the soil in gerboxes (Londrina-PR, 2011)

\begin{tabular}{llllllll}
\hline Treatment & & & & & & & \\
\hline
\end{tabular}

${ }^{\mathrm{a}}$ Benzalkonium chloride.

${ }^{\mathrm{b}}$ Commercial product based on $\boldsymbol{T}$. harzianum

${ }^{\mathrm{c}}$ Data transformed into $\log \mathrm{x}$.

${ }^{\mathrm{d}}$ Means followed by the same letter in the column did not differ significantly in the Scott-Knott test at $5 \%$ error probability. 
results for carbendazim, procymidone, thiophanatemethyl, and T. harzianum (Table 1).

Applying the fungicides did not influence the development of NS, which ranged from 3.3 to $16.5 \%$, and there was no significant difference $(\mathrm{P}<0.05)$ between treatments (data not shown).

In this experiment, apothecia grown with the application of each treatment were crushed, and the number of germinated ascospores was evaluated. The percentage inhibition of germination was calculated in comparison with the control. Benzalkonium chloride + fluazinam and procymidone were the most effective treatments. They inhibited 13.9 and $13.5 \%$ of germination; this finding differed statistically $(\mathrm{P}<0.05)$ from that for other treatments, which produced a low level of inhibition that ranged from $9.8 \%$ (carbendazim) to $0.6 \%$ (T. harzianum). No ascospores were produced after treatment with fluazinam (because no apothecia developed in the gerbox, there were no ascospores to evaluate).

With regard to numbers of ascospores/ apothecium, benzalkonium chloride + fluazinam and procymidone produced 17,100 and 33,600 ascospores.apothecium $^{-1}$, respectively, whereas the control produced 98,000 ascospores.apothecium ${ }^{-1}$. These treatments resulted in reductions of $82.4 \%$ and $65.6 \%$. However, none of the fungicides produced statistically different results $(\mathrm{P}<0.05)$, but all differed from results for the control $(98,000$ ascospores. apothecium $^{-1}$ ) and treatment with $\boldsymbol{T}$. harzianum $\left(58,000\right.$ ascospores.apothecium $\left.^{-1}\right)$.

Fungicide inhibition of ascospore germination of $\boldsymbol{S}$. Sclerotiorum in Petri dishes

Treatments with fluazinam and benzalkonium chloride + fluazinam completely inhibited ascospore germination and were statistically identical $(\mathrm{P}<0.05)$ to treatment with carbendazim (95.9\% inhibition). The results obtained for thiophanate-methyl (70.1\%), iprodione (35.7\%), procymidone $(7.5 \%)$, and $\boldsymbol{T}$. harzianum $(0.2 \%)$ differed statistically $(\mathrm{P}<0.05)$. Treatment with the commercial product based on T. harzianum was least successful in inhibiting ascospore germination and did not differ from the control (data not shown).

Chemical control of Sclerotinia stem rot in the soybean crop

In the 2009-10 harvest, all treatments were effective in controlling Sclerotinia stem rot (Table 2) in comparison $(\mathrm{P}<0.05)$ with the control (incidence of $79.4 \%$ ). The most effective treatments were procymidone (incidence of $21.3 \%$ ), benzalkonium chloride + fluazinam (21.3\%), and fluazinam $(22.5 \%)$, which achieved reductions in the incidence of Sclerotinia stem rot of $73.1 \%, 73.1 \%$, and $71.6 \%$, respectively, in comparison with the control. With regard to severity of Sclerotinia stem rot, the control exhibited $73.9 \%$ severity; this differed statistically $(\mathrm{P}<0.05)$ from treatments with procymidone $(7.8 \%$ severity), benzalkonium chloride + fluazinam $(11.5 \%)$, and fluazinam (13.6\%). It also exhibited cutting severity by $89.4 \%, 84.4 \%$, and $81.5 \%$, respectively. The best yields were obtained using benzalkonium chloride + fluazinam, fluazinam, procymidone and carbendazim, with higher yields $(\mathrm{P}<0.05)$ than those of other treatments. There was a high negative correlation between the incidence and the yield and between severity and the yield, with correlation coefficients of -0.60 and -0.76 , respectively. This finding indicated that the yield increased as treatments reduced the incidence and severity of the disease.

In the 2010-11 harvest, the initial inoculum concentration observed was 11 sclerotia. $\mathrm{m}^{-2}$ with $83 \%$ viability, and the results were similar for the 2009-10 harvest with regard to the incidence and severity, in which treatment with fluazinam, procymidone, and benzalkonium chloride + fluazinam surpassed other treatments, with respective figures of 77.6, 75.7, and $77.6 \%$ control. However, there were no significant differences in the yield between treatments, probably because the incidence and severity of the disease had not reached levels that could cause losses and influence yield. As in experiment 1, a strong negative correlation was observed between the incidence and the yield, and between the severity and the yield, with correlation coefficients of -0.69 and -0.69 , respectively.

The commercial product based on $\boldsymbol{T}$. harzianum was not effective in reducing the damage caused by Sclerotinia stem rot in the soybean crop under field conditions, and the results did not differ statistically $(\mathrm{P}<0.05)$ from those for the control for the majority of parameters evaluated, with the exception of the incidence in the 2009-10 harvest.

\section{DISCUSSION}

The fungicides inhibited $\boldsymbol{S}$. sclerotiorum resistance structures, fruiting body, and spores and pathogen development under field conditions. The biological product based on Trichoderma also showed efficient inhibition of carpogenic and ascospore germination. However, although there are many reports of the success of biological control against Sclerotinia stem rot, the biological control 
Table 2 - Incidence and severity of Sclerotinia stem rot treated with fungicides, soybean yields for the 2009-2010 and 2010-2011 harvests (Mauá da Serra, Paraná, Brazil).

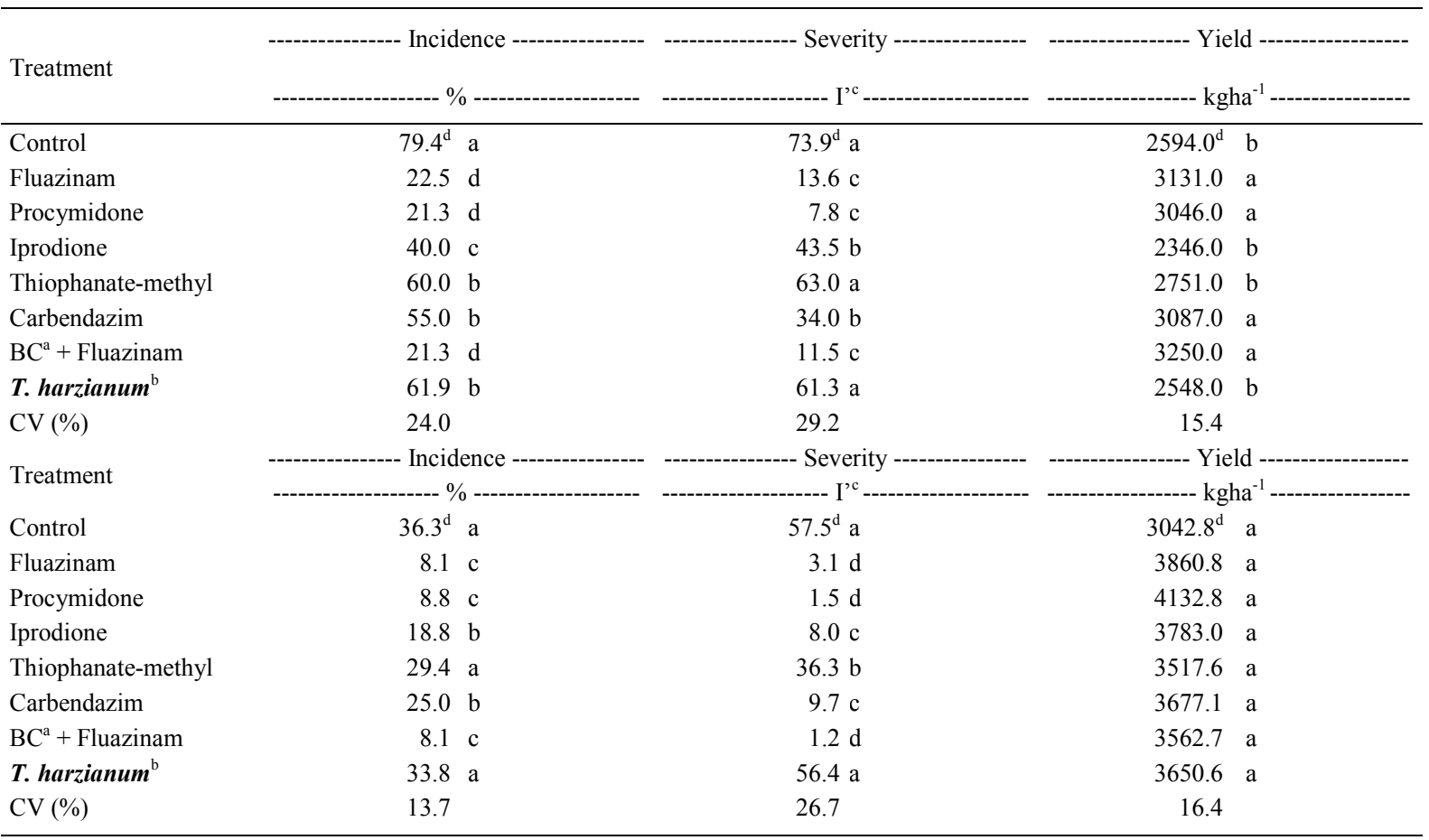

${ }^{a}$ Benzalkonium chloride.

${ }^{\mathrm{b}}$ Commercial product based on $\boldsymbol{T}$. harzianum .

${ }^{\mathrm{c}}$ Infection intensity index as a percentage.

${ }^{\mathrm{d}}$ Means followed by the same letter in the column did not differ significantly in the ScottKnott test $(\mathrm{P}<0.05)$.

of $\boldsymbol{S}$. sclerotiorum under field conditions was not effective. The use of biological control under field conditions is highly sensitive to the success of the establishment of biocontrol agents.

Similar reports of the chemical fungicide control of $\boldsymbol{S}$. sclerotiorum are available COSTA \& COSTA(2004) tested the efficacy of several fungicides applied to the soil to inhibit myceliogenic and carpogenic germination of sclerotia. Of the fungicides evaluated, fluazinam resulted in $100 \%$ inhibition of apothecia, procymidone in $95 \%$ inhibition, iprodione $85 \%$ inhibition, and thiophanate-methylin less than $85 \%$ inhibition. The authors reported that fluazinam was completely effective in inhibiting the formation of apothecia but not the formation of stipes. This is in agreement with the results obtained in our study, in which carpogenic germination was completely inhibited but stipe production remained unaffected. However, efficacy in controlling the disease is based on the inhibition of the apothecium, as even if stipes are formed, if apothecia do not develop and release ascospores, the disease is controlled.
Studies of the action of fungicides on the ascospores germination of S. sclerotiorum are few. In this study, in addition to observing the positive effect of chemical treatments on inhibiting apothecia production by sclerotia, it was observed the effect on the number of germinated or viable ascospores produced. The reduction observed in the number of ascospores and the decrease in ascospore germination can cause a decrease in the number of plants infected under field conditions due to the lower quantity of inoculum released, in addition to the possibility of nonviable ascospore production.

Many in vivo studies have been conducted to evaluate the efficacy of fluazinam and procymidone in the control of diseases caused by $\boldsymbol{S}$. sclerotiorum in common bean crops (PAULA JÚNIOR et al., 2009).

Fluazinam affects infection processes such as spore germination, formation of appressoria, hyphae penetration and growth, and pathogen sporulation in plants by uncoupling mitochondrial oxidative phosphorylation. Procymidone paralyzes the growth of hyphae, causing swell, bursting the cell 
wall, ejecting the cytoplasmic contents, and inhibiting protein, nucleic acid, and lipid synthesis and spore germination (PICININI \& GOULART, 2002). According to REIS et al. (2010), dicarboximide fungicides (procymidone) probably also use another mechanism involving peroxidized lipids interacting with cytochrome-c flavin reductase. The transport of NADPH electrons to cytochrome-c is blocked by the fungicide's action, and as a result, NADPH and essential phospholipids that surround the center of the flavin enzyme are oxidized, probably by a flavin enzyme intermediate or free radicals. In this study, it was observed significant differences in the effectiveness of fluazinam and procymidone in the in vitro tests of the inhibition of mycelial growth, carpogenic germination, and ascospore germination (by direct application of the fungicide to ascospores). The control achieved by these fungicides was statistically the same $(\mathrm{P}<0.05)$ only in the field trials and both cropping years. PICININI \& GOULART (2002) reported on the action of both fungicides in inhibiting spore germination but obtained better results using fluazinam. The difference observed in the in vitro and field tests is probably due to the mode of action of the fungicides. Fluazinam is a non penetrating (contact) residual protectant fungicide that acts on the pathogen on the plant's surface, inhibiting structural development and preventing penetration. Procymidone is a systemic fungicide that acts inside the plant and takes effect after the fungus has penetrated, when symptoms of the disease are already present.

In summary, fluazinam showed the greatest efficacy in inhibiting mycelial growth, carpogenic germination, and ascospore germination in vitro and in controlling Sclerotinia stem rot in commercial soybean crops. Procymidone showed the same potential as fluazinam in both agricultural years in controlling Sclerotinia stem rot under field conditions.

Regarding conventional recommendations for the use of fungicides to control Sclerotinia stem rot, MUELLER et al. (2004) commented that application should be at the onset of flowering and possible reapplication after blooming, reducing the incidence of the disease and boosting yields. However, it is very difficult to control diseases caused by sclerotia-forming fungi by applying specific fungicides to inhibit sclerotia in the field (COSTA $\&$ COSTA, 2004). Inconsistent results regarding the control of Sclerotinia stem rot using fungicides are probably due to inadequate coverage on the plant canopy, flowers, stems, and leaves where ascospores are usually deposited. According to TU (1989), the fungicide must be applied in sufficient volume to cover flowers, stems, and leaves completely and particularly the structures closest to the soil surface.

\section{CONCLUSION}

Fluazinam and procymidone showed the highest efficiency in controlling Sclerotinia stem rot in a soybean crop under field conditions. Carpogenic and ascospore germination in vitro was efficiently inhibited with fluazinam alone.

\section{ACKNOWLEDGEMENTS}

The financial support of the Coordination for the Improvement of Higher Education Personnel.

\section{REFERENCES}

ABDULLAH, M.T. et al. Biological control of Sclerotinia sclerotiorum (Lib.) de Bary with Trichoderma harzianum and Bacillus amyloliquefaciens. Crop Protection, v.27, p.1354-1359, 2008. Available from: <http://www.sciencedirect.com/science/ article/pii/S026121940 8000926>. Accessed: 18 jan. 2013. doi: 10.1016/j.cropro.2008.05.007

AMARAL, E. Novo índice de intensidade de infecção. Pesquisa Agropecuária Brasileira, v.4, p.1-2, 1969.

BARDIN, S.D.; HUANG, H.C. Research on biology and control of Sclerotinia diseases in Canada. Canadian Journal of Plant Pathology, v.23, p.88-98, 2001.

COSTA, J.R.; COSTA, J.L. da S. Efeito da aplicação de fungicidas no solo sobre a germinação carpogênica e miceliogênica de escleródios de Sclerotinia sclerotiorum. Pesquisa Agropecuária Tropical, v.34, p.133-138, 2004.

DHINGRA, O.D. et al. Doenças e seu controle. In: SEDIYAMA, T. Tecnologias de produção e usos da soja. Londrina: Mecenas, 2009. p.133156.

FERRAZ, L.C.L. et al. Viabilidade de Sclerotinia sclerotiorum após a solarização do solo na presença de cobertura morta. Fitopatologia Brasileira, v.28, p.17-26, 2003. Available from: <http://www.scielo. br/scielo.php?script=sci_arttext\&pid=S0100-41582003000100003>. Accessed: 01 out. 2014. doi: 10.1590/S0100-41582003000100003.

GRAU, C.R. et al. Resistance of soybean cultivars to Sclerotinia sclerotiorum. Plant Disease, v.66, p.506-508, 1982. Available from: $<$ http://www.apsnet.org/publications/PlantDisease/BackIssues/ Documents/1982Articles/PlantDisease66n06_506.PDF>. Accessed: 01 out. 2014. doi: 10.1094/PD-66-506.

HJELJORD, L.; TRONSMO, A. Trichoderma and Gliocladium in biological control: an overview. In: HARMAN, G.E.; KUBICEK, C.P. Trichoderma and Gliocladium: enzymes, biological control and commercial applications. Londres: Taylor \& Francis, 2005. p.115-133.

HUANG, H.; ERICKSON, R.S. Factors affecting biological control of Sclerotinia sclerotiorum by fungal antagonists. Journal of Phytopathology, v.156, p.628-634, 2008. Available from: $<$ http:// eds.b.ebscohost.com/eds/pdfviewer/pdfviewer?sid=eccc9188- 
a316-4038-9c8c-c8f7edf55a5d\%40sessionmgr 198\&vid =1 \&hid=117>. Accessed: 10 out. 2014. doi: 10.1111/j.14390434.2008.01423.x

LOBO JUNIOR, M.; ABREU M.S. de. Inibição do crescimento micelial de Sclerotinia sclerotiorum por metabólitos voláteis produzidos por alguns antagonistas em diferentes temperaturas e ph's. Ciência e Agrotecnologia, v.24, p.521-526, 2000.

MUELLER, D.S. et al. Efficacy of fungicides on Sclerotinia sclerotiorum and their potential for control of Sclerotinia stem rot on soybean. Plant Disease, v.86, p.26-31, 2002. Available from: <http://apsjournals.apsnet.org/doi/pdf/10.1094/ PDIS.2002.86.1.26>. Accessed: 20 out. 2014. doi: 10.1094/ PDIS.2002.86.1.26

MUELLER, D.S. et al. Application of thiophanate-methyl at different host growth stages for management of Sclerotinia stem rot in soybean. Crop Protection, v.23, p.983-988, 2004. Available from: <http:// www.ars.usda.gov/SP2UserFiles/ad hoc/54000000WhiteMold Research/PublicationPDFs/Applicationofthiophanate.pdf $>$. Accessed: 20 out. 2014. doi: 10.1016/j.cropro.2004.02.013.

PAULA JÚNIOR, T.J. et al. White mold intensity on common bean in response to plant density, irrigation frequency, grass mulching,
Trichoderma spp., and fungicide. Summa Phytopathologica, v.35, p.44-48, 2009. Available from: <http://www.scielo.br/pdf/ sp/ v35n1/v35n1a07.pdf>. Accessed: 20 out. 2014. doi: 10.1590/ S0100-54052009000100007.

PICININI, E.C.; GOULART, A.C.P. Novos fungicidas para tratamento de sementes. Revisão Anual de Patologia de Plantas, v.10, p.33-66, 2002.

REIS, E.M. et al. Manual de fungicidas: guia para o controle químico de doenças de plantas. 6.ed. Passo Fundo: Universidade de Passo Fundo, 2010.

SARMA, B.K. et al. Use of non-conventional chemicals as an alternative approach to protect chickpea from Sclerotinia stem rot. Crop Protection, v.26, p.1042-1048, 2007.

TU, J.C. Management of white mold of white bean in Ontario. Plant Disease, v.73, p.281-285, 1989.

WRATHER, J.A.; KOENNING, S.R. Effects of diseases on soybean yields in the United States 1996 to 2007. Available from: <http://www.plantmanagementnetwork. org/pub/php/Research/2009/yields/>. Accessed: 20 out. 2014. doi: 10.1094/PHP-2009-0401-01-RS. 